\title{
Review on methods for preservation and natural preservatives for extending the food longevity
}

\author{
Z.I.M. Sharif ${ }^{1}$, F.A. Mustapha ${ }^{1}$, J. Jai ${ }^{1 *}$, N. Mohd.Yusof ${ }^{1}$, N.A.M. Zaki ${ }^{1}$ \\ ${ }^{I}$ Faculty of Chemical Engineering, Universiti Teknologi Mara (UiTM), 40450 Shah Alam, Selangor, Malaysia. Article \\ Info: Submitted on March 20, 2017, Accepted on June 20, 2017.
}

\begin{abstract}
Chemical, enzymatic or microbial activities from the surrounding environment and the food itself can cause spoilage to food products. In the meantime, the recent surge in world population, calls forfood products to be stored and delivered from one place to another place. During delivery, food products will start to deteriorate, losetheir appearance and decrease in nutritional values. Thus, the presence of food preservation methods such as heating, pickling, edible coating, drying, freezing and high-pressure processing can solve this problem by extending the food products' shelf life, stabilize their quality, maintaining their appearance and their taste. There are two categories of food preservations, the modern technology preservation method and the conventional preservation method. In the meantime, conventional food preservations usually use natural food preservatives. Meanwhile, the use of the synthetic preservative such as sulphites, benzoates, sorbates etc. for food preservation can cause certain health problems. In this light, replacing these synthetic preservatives with natural preservatives such as salt, vinegar, honey, etc. are much safer for human and environment. Furthermore, natural preservatives are easy to obtain since the sources are from plant, animal and microbes origin. This review paper focuses on preservation methodsand the natural preservatives that are suitable to be used for food preservation.
\end{abstract}

Keywords: Preservation; Natural preservatives; Antimicrobial agents; Antioxidation agents; Foods.

\section{Introduction}

Food can be raw, processed or formulated materials consumed by human and animals to produce energy, promotes growth, and to maintain good health. In most cases, there are no limitations on food consumption. However, the excessive consumption of certain types of food such as fat, sugar and salt, may be harmful to health. Chemically, food products consist of water, fat, carbohydrates, protein and small amounts of organic compounds and minerals. Thus, it will promote the growth of microbial since all these compounds are the source energy for microbial to grow. To prevent this from occurring, various preservation methods are proposed four different classes of food depending on their properties. ${ }^{1}$ There are 6 classes of food based on the food pyramid, which are fats and sugar (cream, butter, sugar, soft drinks, etc.), dairy products (yogurt, cheese, milk, etc.), protein (poultry, eggs, meat, nuts, etc.), vegetables (tomatoes, salad, spinach, etc.), fruits (apples, mangoes, banana, etc.) and lastly, carbohydrates (bread, rice, noodles, etc.). ${ }^{2}$

The retention of food quality is important to ensure the consumption of food with high nutritional values for our health. Thus, the best way to retainfood quality and prevent them from deteriorating is by preservation methods. Nowadays, there are various types of preservation methods that can be applied to maintain the condition of food products for a long period of time, either by using the conventional or modern preservation technology methods. Some of these preservation methods use additional food preservatives which can be classified into artificial and natural preservatives. Generally, consumers are aware of the short and long term effects of using artificial preservativesto their health. Thus, the demands of using natural preservatives in food are highly increasing. This review paper focuses on, (1) the preservation methods of food to maintain or protect the quality of food, and (2) the use of natural food preservatives as alternative to artificial preservatives, for safer human consumption.

\section{Food Preservation Methods}

Preservation of food has been used since ancient times. The preservation process will restrain the development of microbial such as bacteria and fungi. ${ }^{3}$ In this light, the aims of food preservations include, first, maintaining food taste, texture, flavour, quality and nutritional value, second, to reduce the wastage of excess food, third, to maintain a product's accessibility for a longer time, even in places it is not being produced, fourth, to preserve the food materials during transportation, and finally, to ease the handling of food materials. $^{4}$

There are various methods that can be used to preserve food, including conventional methods and modern preservation technology. Some of the conventional 


\section{Chemical Engineering Research Bulletin 19(2017) 145-153}

methods like drying processes have been improved through time for the convenience of large food industry. Here are some of the examples of preservation methods.

Thermal or heating processing is one of the methods used to preserve fruits. Thermal processing is the technology that is applied to prolong the shelf life and increasethe longevity of fruits and vegetables. ${ }^{5}$ This is because the process is productively decreasing the growth of microbial population and pulverizes the natural enzymes. ${ }^{6}$ This thermal process has extensively been used for the production of jams and jellies, canned and bottled fruits and vegetables. In general, fruits and vegetables in cans and bottles are produced under commercial sterility can be used up to 2 years and longer. Thermal processing is the process of either heating unsterile foods in containers such as canning, or heating food products, prior to packaging or before they are put under sterile states such as aseptic handling. ${ }^{6}$ Besides that, this method also used in the process of milk pasteurization.

Drying is another food preservation technique that has long been utilized. Food products can be dried using various techniques, such as drying under the sun (natural drying) or by using simulated heat under controlled temperature, which using the specially developed chambers called dehydrators or dryers. ${ }^{4}$ While this technique is commonly used for meat and fish, it can also be applied to fruits and vegetables. As a result, dried fruit and vegetable products will be lighter in weight, hence, the delivery cost of dried products can be reduced. ${ }^{5}$ The moisture content of the food is reduced to $10-15 \%$, thus, the present microorganisms can be inhibited and become inactive. ${ }^{7}$ The moisture content can be evaporated by using either sun drying or under controlled temperature. ${ }^{4}$ However, further dehydration is not recommended because regularly, the product will regularly be too brittle. Meanwhile, to guarantee that the fruits will not be damaged during the drying process they should be kept in a free-moisture environment. On the other hand, many studies have claimed that drying will degrade the quality of the products. ${ }^{7}$

Drying process can be divided into two types, natural drying and artificial drying. Natural drying is drying in the open surrounding and using economical procedure. It does not need any energy consumption, it only uses of sunlight and wind. Fruits will be dried in thin layers and turned routinely under sunlight. In the meantime, there are few methods for artificial drying, which are heated with fuel, with bush dryer, air dryers with artificial ventilation and others. Heating with fuel is the technique usually used in wet climates or when there are an abundant of fruits need to be processed. The bush dryer is the fire in an oven that is produced using oil drums to heat the surrounding air. The heated air will ascend through the thin layer of fruits that is placed on the racks and should be shaken or blended at general interims with regular monitoring. The last method is using the air dryer with an artificial ventilation technique. A motor controlled ventilator can be utilized to blow warm air from the motor or warming the air using a burner through the products. ${ }^{7}$

Pickling is the technique where food is preserved in common salts or vinegar. Nutrients contained in pickles depend on the ingredient used for making them and, usually, pickles are low in calories. This method has been used since a long time ago to preserve fruits and vegetables. Pickles are usually eaten as the appetizer. They stimulate the production gastric juice, which helps in food digestion. For making pickles, fruits and vegetables are added with 8 to $10 \%$ of salt and 3\% of vinegar. After that, they will be kept for 6 to 8 days under the sun with the temperature of $29^{\circ} \mathrm{C}$ to $30^{\circ} \mathrm{C}$ for fermentation with the assistance of lactic acid bacteria. In the last step, it will be blended together with coarsely powder spies and then, it will be covered completely with moisture-free edible oil. Pickles ought to be kept an additional 3 weeks in the sun. ${ }^{4}$

Freezing is one of the easiest and most economical way to preserve foods. Most products contain enzymes that can destroy the nutrients in the food. In this light, this enzyme will change the appearance and texture of the product during storage. Freezing will stop the development of microbial however, will not kill them. ${ }^{8}$ Freezing is being categorized as a form of preservation because it can reduce the water level activities which will inhibit the microbial activity and decrease the chemical reaction rates. As a result, thermal exposure in frozen foods is low. At the same time duringfreezing and defrosting processthe tissue structure of the food will damage and it is occurringdue tothe rate and temperature applied. This will lead to the deterioration of texture, colour and the taste. Freezing food loss more nutrients during storage due to the oxidation process occurred. ${ }^{6}$ Even though it is the easiest method of preservation, but the process occurred is complex due to the involvement of heat transfer and also the changes in chemical and physical series that affect the food products' quality. ${ }^{9}$ Research done by Kim et. al. ${ }^{10}$ on the use of different types of freezing techniques, followed by using different types of thawing for pork quality in ready to eat meals. The results show that of time and rates of freezing is the factors that affect the quality of meat.

High-pressure processing are also known as ultra-high pressure is the alternative way that can replace heating process because this method does not only change, but maintain their organoleptic properties. This method had been used successfully against the microorganisms due 


\section{Chemical Engineering Research Bulletin 19(2017) 145-153}

to the ruptureof their cell membranes. ${ }^{6}$ In this regard, food products will be exposed to the high pressure in a short period of time, either with or without the addition of heat, so the microbial activities will be deactivated. This method will not break the covalent bond, thus, it will maintain the quality of the food and their freshness. ${ }^{11}$ In the meantime, high-pressure sterilization, which is accomplished by using high introductory temperature. Microwaves, pulsed electric fields and radiation,which appliesradian energy, changes the food as they are assimilated, while ohmic processing will increase the food temperature itself when the electric current is passing by through them. ${ }^{6}$ As high-pressure process acts directly and evenly throughout the food, this process depends on their shape, composition and size. The food will be compressed evenly, thus, it will increase the temperature of the food roughly at the rate of $3^{\circ} \mathrm{C}$ per $100 \mathrm{MPa}$ and it will rise evenly because of the compression. Microbial will be inactivated at the temperature range of $45^{\circ} \mathrm{C}$ to $50^{\circ} \mathrm{C} .^{12}$

Edible coating technique is another preservation method which can be used to maintain the food condition. This method has been broadly considered for preservation of fruits and vegetables. This increases the public demands in the development of edible coatings which will replace the synthetic waxes for maintaining the quality of postharvest fruits. ${ }^{13}$ Edible substances such as protein, polysaccharides and lipids will be enforced on the surface of the product to form a thin layer ${ }^{14}$ Edible coating is anecologically well-disposed innovation that has been applied on numerous products to control moisture transfer, exchange gases or the oxidation process. ${ }^{15}$ Nevertheless, edible coating is able to prolong the fresh cut product shelf life by reducing the respiration and conserve their organoleptic properties. ${ }^{14}$ Nowadays, edible coating technique has been applied with the additional of food additives in the coating formulation such as antimicrobial agents, antioxidant agents, and stabilizer. Furthermore, the addition of food additives will help to extend the shelf life of food. ${ }^{16}$ As an example, the incorporation of an edible coating of antimicrobial agent is one of conducive method to attain the antimicrobial activity ${ }^{17}$ Studies presented in few literatureshave shown that the potential applications of this method on foods, such findings arebeing summarized in Table 1.

\section{Natural Food Preservatives}

Food preservative is the food additive used to preserve food by lowering down the $\mathrm{pH}$ value and settling the redox potential of the food. ${ }^{18}$ Moreover, it is also used as the preservatives that hinder the development of the microbial in the food product or to avoid food spoilage from occur. ${ }^{3}$ Food preservatives are divided into two classes, Class I and Class II. Class I is known as the natural preservatives while Class II is the artificial or chemical preservatives.

However, only one type of Class II preservatives should be used in a particular food product because it can cause harm for people who over-consumed them as examples sulphites, benzoates, sorbates etc. ${ }^{19}$. The classification of both classes of preservatives are shown in Figure 1.

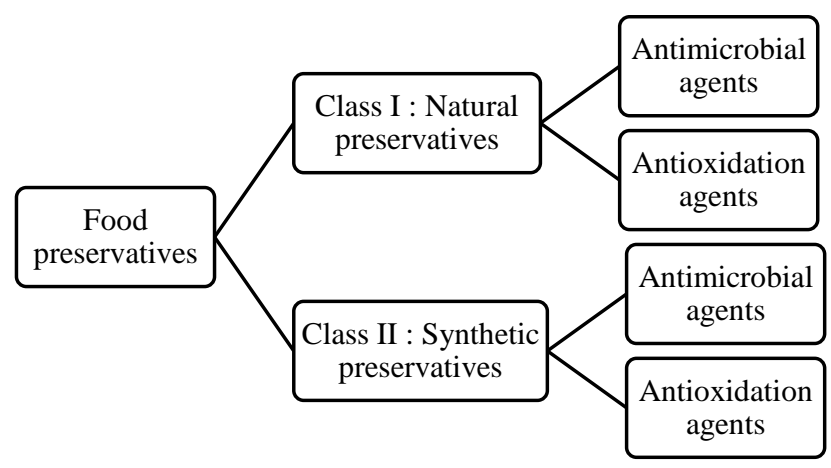

Figure 1: Categories of food preservatives ${ }^{19}$.

Nevertheless, the use of preservatives has its own advantages and disadvantages. The advantages of using preservatives include maintaining food consistency and nutritional value, protecting the food from microbial and to enhance its flavour. On the other hand, their disadvantage is their over-consumed can cause health problems, such as asthma, kidney failure and cancer. ${ }^{20}$ However, this review paper only focuses on the natural food preservatives that has been classified into two agents which are antimicrobial agent and antioxidant agent. Natural food preservatives usually from plant origin, animals origin and microbial origin. ${ }^{18}$ 


\section{Chemical Engineering Research Bulletin 19(2017) 145-153}

\section{Antimicrobial Agent}

Antimicrobial agents are known as the substance that is utilized to preserve food which inhibit the development of microorganisms and deterioration. This definition has been defined by the U.S Food Drug Administration. $^{21}$ Nowadays, the use of natural are highly potential against the food spoilage microorganism and food borne pathogens. ${ }^{22}$

\section{Antimicrobial agent - plant origin}

Plant can be used as the source for natural antimicrobial agents because it has lots of important bioactive

Table 1: Summary of edible coating studies.

\begin{tabular}{|c|c|c|c|c|}
\hline Types of based & Composition & Food Additives & Application \& Results & Ref. \\
\hline \multirow[t]{3}{*}{ Polysaccharides } & $\begin{array}{l}\text { Chitosan, distilled } \\
\text { water, Tween } 80, \\
\text { palm stearin }\end{array}$ & $\begin{array}{l}\text { Chitosan } \\
\text { (Anti-microbial } \\
\text { agent) }\end{array}$ & $\begin{array}{l}\text { Chitosan-stearin edible coating on } \\
\text { star fruits (Averrhoa carambola } L .) \\
\text { are able to extend the shelf life at } \\
\text { low temperature and maintaining } \\
\text { their firmness and appearance. }\end{array}$ & 48 \\
\hline & $\begin{array}{l}\text { Cassava starch, } \\
\text { copaiba oil, } \\
\text { distilled water }\end{array}$ & $\begin{array}{l}\text { Copaiba oil } \\
\text { (Anti-microbial } \\
\text { agent) }\end{array}$ & $\begin{array}{l}\text { Coating with cassava starch and } \\
\text { copaiba oil on organic strawberry at } \\
\text { low temperature shows the lower } \\
\text { counts of mesophilic and } \\
\text { psychotropic microorganism, yeast } \\
\text { and mould. }\end{array}$ & 49 \\
\hline & $\begin{array}{l}\text { Chitosan, glycerol, } \\
\text { Tween } 80 \text {, distilled } \\
\text { water }\end{array}$ & $\begin{array}{l}\text { Chitosan (Anti- } \\
\text { microbial agent) }\end{array}$ & $\begin{array}{l}\text { Coating based on chitosan-glycerol } \\
\text { to delay "Berangan" banana } \\
\text { ripening process at ambient air is an } \\
\text { effective method. }\end{array}$ & 50 \\
\hline $\begin{array}{l}\text { Polysaccharide } \\
\& \text { Protein }\end{array}$ & $\begin{array}{l}\text { Whey protein, soy } \\
\text { protein, alginate, } \\
\text { carrageenan, } \\
\text { glycerol, distilled } \\
\text { water }\end{array}$ & $\begin{array}{l}\text { Alginate \& } \\
\text { sunflower oil } \\
\text { (Anti-oxidation } \\
\text { agent) }\end{array}$ & $\begin{array}{l}\text { Effect of using different based of } \\
\text { edible coating on fresh cut apples to } \\
\text { extend their shelf life. The whey } \\
\text { protein and soy protein is the most } \\
\text { effective properties for coating and } \\
\text { additional of sunflower oil helps to } \\
\text { improve the fruits quality. }\end{array}$ & 51 \\
\hline \multirow[t]{2}{*}{ Protein } & $\begin{array}{l}\text { Soy protein, lauric } \\
\text { acid, } \\
\text { propyleneglycol, } \\
\text { distilled water }\end{array}$ & - & $\begin{array}{l}\text { Using soy protein based is } \\
\text { improving the shelf life and overall } \\
\text { quality of minimal process jujubes. }\end{array}$ & 52 \\
\hline & $\begin{array}{l}\text { Gum acacia, } \\
\text { garlic, cinnamon }\end{array}$ & $\begin{array}{l}\text { Garlic, cinnamon } \\
\text { (Anti-microbial } \\
\text { agent \& Anti- } \\
\text { oxidation agent) }\end{array}$ & $\begin{array}{l}\text { Gum acacia edible coating } \\
\text { incorporated with garlic and } \\
\text { cinnamon as natural preservative for } \\
\text { meat and fish shows garlic and } \\
\text { cinnamon can be used as the } \\
\text { antimicrobial and antioxidant agent. } \\
\text { The shelf life is extended until } 3 \\
\text { weeks and the microbial present } \\
\text { decrease week wise. }\end{array}$ & 53 \\
\hline
\end{tabular}

antimicrobial agent in preservation had high demand by consumers because they has been exposed and aware about the effect of using synthetic preservatives. Moreover, compounds that derived from natural sources compounds such as phenolic, terpenes and alkaloid. These compounds usually present in certain parts or all parts of the plant. ${ }^{23}$ Plants formed high diversity of secondary metabolites has function to protect the plants 


\section{Chemical Engineering Research Bulletin 19(2017) 145-153}

from predator and microbial pathogen because of their properties that can oppose microbial. ${ }^{24}$ One of the largest group present in the secondary metabolite compound is the phenolic and polyphenols groups. There are also a few of sub-group compound that also important for inhibition of microbial activity which are flavonoids, quinones, coumarins, phenolic acids, tannins, phenols, flavones and flavonols. Phenol is the compound that contains hydroxyl $(-\mathrm{OH})$ group. The sites and number of phenol group present in the compound are thought to be identified with their relative harmfulness to the microorganisms. The higher the number of the hydroxyl group present, the higher the toxicity. ${ }^{25}$ Today, more than 1340 plants have the properties of antimicrobial and over 30000 antimicrobial compounds has been extracted from plants. $^{26}$

United States Food and Drug Administration (FDA) states that numerous essential oils has been recorded as Generally Recognized as Safe (GRAS) and might be utilized for food preservatives. ${ }^{27}$ Essential oil is the most important phytochemical that can be used in food preservatives. ${ }^{28}$ Essential oils have volatile properties and sweet-smelling substance with an oily consistency which normally formed by plants. They can be extracted from different part of plants such as flowers, seeds, leaves, etc. Several methods can be used to extract essential oils from various part of aromatic plants for examples distillation, supercritical fluid and many others. The oxygenated terpenoids (e.g. alcohol and phenolic terpenes) function as the antimicrobial agents of the essential oils. However, several hydrocarbons have properties to exhibit the microbial activity such as aliphatic, monoterpene and sesquiterpenes hydrocarbons. ${ }^{24}$ Herbs and spices have been utilized since a long time ago for various purposes including as antimicrobial agents. Extraction of essential oil from plants, spices and herbs have high vapour pressure and able to reach the microbial through liquid and gas phases. ${ }^{26}$ Hydrophobic properties in essential oils will react with lipids at the cell membrane of the microbial and degrade the cell wall of the microbial. Thus, will increase the permeability of the cell and damage the cytoplasmic membrane. The cell content will be leakage and coagulation of cytoplasm will be occurred. As results, it will disturb the origin structure of the cell. ${ }^{34,36}$

Study made by Bitencourt et. al. ${ }^{27}$,shows the inhibitory of Escherichia Coli and Salmonella Enteritidis was resolved through the standard broth dilution technique using two-fold dilution of mint essential oil. As the outcomes, the development of Escherichia Coli and Salmonella Enteritidis are inhibited by using the edible coating that contains mint essential oil. The higher the mint essential oil concentration, the lower the microbial activity. Matan ${ }^{29}$, studies shows the results used of anise oil that contains several active compounds such as trans-anethole, $\alpha$-trans-bergamotene, and limonene can inhibit bacteria like Salmonella Typhimurium, Staphylococcus Aureus,Vibrio Parahaemolyticus, etc. These microbial usually be found in the fish product. Moreover, anise oil could also hinder the spore germination. Besides that, Matan ${ }^{29}$ also reported that cinnamon and clove oil are containing lots of component active compound as example cinnamaldehyde, eugenol and linalool. Thus, both oils are capable of stopping the development of microbial.

\section{Antimicrobial agent - animal origin}

Animal is one of sources of antimicrobial agent that is safe to be consumed by the consumers. As the example the used of chitosan which has been widely used in food industries. Chitosan is the polycationic biopolymer that commonly can be found in exoskeletons of crustaceans such as crabs or lobsters. The used of chitosan in food preservation has its limitation due to its properties that cannot be dissolved in neutral condition and higher $\mathrm{pH}$ value. ${ }^{22}$ Nowadays, chitosan is used incorporated with edible coating and film, which helps to reduce the water vapour content, prevent oxygen transmission and extending the shelf life of fruits. Thus, this will prevent deterioration of food. ${ }^{30}$ Other than chitosan, lysozyme that present in eggs and milk can also be used as antimicrobial animal origin and it has being recognized as safe (GRAS). Lysozyme enzyme that present in eggs commonly been applied as an antimicrobial agent and preservative for poultry product, meat, fruits and so forth. Lysozyme has the properties as antimicrobial because of its ability to hydrolyze $\beta-1,4$ linkage between $\mathrm{N}$-acetylmuramic acids and $\mathrm{N}$-acetyl glucosamine at the cell wall of the microbial.$^{22}$ Lysozyme is well known being used commercially to prevent late blowing for semi-hard cheese that caused by Clostridium tyrobutyricum. Lysozyme usually can against Gram-positive bacteria but not the Gramnegative bacteria. This is because of the lipopolysaccharide layer presence on the surface of the cell membrane. ${ }^{30}$

As reported by Murdock et. al. ${ }^{31}$,lactoferrin is one of natural antimicrobial agents that can be found from mammalian secretion such as saliva, milk, tears, etc. and it has been stated that it is one of the strongest antimicrobial agentsin milk. Lactoferrin will limit the number of iron present in the surrounding environment. Therefore, this condition will hinder the development of the bacteria cell. Then, liposaccharides will be free from the outer membrane of gram-negative bacteria and cause distortion at the outer membrane. Thus, pores or 'blebs' will be formed. It has been proved that 


\section{Chemical Engineering Research Bulletin 19(2017) 145-153}

lactoferrin can inhibit the microbial activity such as Escherichia Coli and L. monocytogenes.

\section{Antimicrobial agent - microbial origin}

There are various compounds that being produced by bacteria which active against other bacteria. These active bacteria can hinder and stop the development of microbial that can lead to food spoilage. ${ }^{32}$ The protein compound known as bacteriocins is the important compound that can act as an antimicrobial agent against spoilage or pathogen microbial. Bacteriocins can be produced by both Gram-positive and Gram-negative bacteria. ${ }^{22}$ These proteinaceous compounds permeating the membrane of cytoplasm and cause intracellular metabolites leakage. Thus, the depletion of membrane is potentially occurring. Besides bacteriocins, there are a few other active bacteria that can effectively inhibit the growth of spoilage microbial such as reuterin and pediosin. ${ }^{32}$

Bacteriocins are produced from lactic acid bacteria such as Lactobacillus acidophilus due to the metabolic activity. ${ }^{33}$ Bacteriocins are capable of inhibiting food borne pathogens such as Clostrisium botulinum, Enterococcus faecalis, Listeria monocytogenes, etc. Furthermore, bacteriocins are safe to be used in biopreservatives because they can be degraded by protease. ${ }^{34}$ Bacteriocins commonly are divided into 4 classifications which depends on their chemical and genetic properties. The famous bacteriocins that commonly listed in both European food additive and the United Stated FDA are nisin. Nisin is widely used in the production of cheese and sausage. ${ }^{33}$

Nisin is formed from Lactococcus lactis and it consists of 34 amino acids such as lanthionine, dehydroalanine, aminobutyric acid and so forth. Nisin is capable of inhibiting various types of Gram-positive bacteria, however, it is not effective against the Gram-negative bacteria because of incapability penetrate the cell wall. ${ }^{35}$ Due to the ionic interaction of the C-terminus, nisin will be attached to the cell membrane of the microbial and pore will be formed. Thus, the materials of the cellular will be released and interruption of the motive force will occur. Nisin should be incorporated with chelators as an example ethylenediaminetetraacetic (EDTA). ${ }^{31}$ Nisin is effectively being used for production of cheese by inhibiting the Staphylococcus aureus that contains in raw milk. ${ }^{36}$

\section{Antioxidation Agent}

Antioxidant agents are commonly being used to extend the food shelf life by preventing the oxidative rancidity, degradation and also changing colour of food from occurring. The natural antioxidant is act as free radical scavengers should consist the phenolic compounds, vitamin $\mathrm{C}$ and vitamin E. ${ }^{37}$ Problems that usually facing by seller are the presence of undesirable melanosis on the surface of fresh-cut fruits and vegetables. ${ }^{38}$

These willchange in the appearance of fruits and vegetables. This is because the reaction occurred on their surface. During this reaction there are two types of enzymes that are involved which are polyphenoloxidase (PPO) and peroxidase (POD) as catalysts. Initially, the hydroxylation will slowly take place which will change the monophenols compounds to diphenols. The second reaction, oxidation of diphenols to quinines will occur and as the results, brownish colour will appear on the fruits or vegetable surface. All these reactions will be held only when the products are being surrounded with the presence of oxygen. The process of handling will be one of the reasons that lead to the beginning of melanosis reaction and the deterioration of foods will occur. ${ }^{39}$ While for poultry, meat, and fish they will face the problem on the lipid oxidation. Most of the lipid oxidation occurred is due to the oxidation of myoglobin species and hemoglobin in the fish muscle. ${ }^{40}$

\section{Antioxidation agent - plants origin}

Plant is one of source of antioxidant agent due to the presence of various types of active compound. Antioxidant compounds are usually can be found in spices, citrus pulp, peel and oil seeds. As examples, black pepper, turmeric, garlic, and so forth is capable of hindering the antioxidant properties in distinct types of food systems. Most of the spices have the ability in antioxidant is because of the presence of active compounds such as lignans, flavonoids, polyphenolic and terpenoids. ${ }^{40}$ Recent years, essential oils are famously being chosen to be used as the antioxidant agent for food preservation due to present of antioxidant compound. These compounds are capable of hindering or postponing the oxidation of lipid for poultry, meat and fish. They will hinder the chain reaction of the oxidation. The presence of the majority compounds of phenolic in essential oils is the main reasons for it being used in food preservation which it will be accountable for antioxidant properties. ${ }^{41}$

As reported by Nugboon and Intarapichet ${ }^{42}$, four types of Thai culinary herbs has been tested for their antioxidant properties which are holy basil, Vietnamese coriander, turmeric and green peppercorn. They will be used in freeze-drying method for pork meatball batter and store it in vacuum packaging at $4^{\circ} \mathrm{C}$. As results, holy basil and green peppercorn show the longer shelf life comparable to turmeric and Vietnamese coriander. However, all the meatballs that havebeen tested with Thai herbs have extended shelf life compared to the control meatballs which it lasts less than 6 days. Studied that reported by Supapvanich et. al. ${ }^{43}$, shows that the used concentration ratio of 1:1 for pineapple 


\section{Chemical Engineering Research Bulletin 19(2017) 145-153}

fruit core extract is effective in order to delay the browning process compares to pulp and peel extract. The used of konjac glucomannan coating incorporated with the pineapple extract has the lowest polyphenol oxidase and peroxidase, but it contains high total phenols content.

\section{Antioxidation agent - animal origin}

The potential sources of natural food preservative compounds have been discovered in various types of natural materials. ${ }^{44}$ Antioxidant agents by animal origin are commonly depended on their free radical scavenging, bleaching inhibition and reducing power. These abilities have been tested in honey. Honey contains active compounds for antioxidant such as phenolic acids, vitamins, enzymes, etc. The flavonoids content in honey shows the strong content of antioxidant activities. In addition, they used fast screening technique and they found that there are few numbers of phenolic acids, flavone (quercetin) and flavanone. Other than vitamins, they believe that these compounds give contribution to the antioxidant capacity for honey samples. ${ }^{45}$

Besides honey, chitosan is the preferable antioxidant agent in animal origin. ${ }^{46}$ Most of the study of oxidative activities of chitosan shows it can delay the lipid oxidation and hinder the reactive oxygen species in biological system and foods. The mechanism of the chitosan in antioxidant activities is able to scavenge the free radicals from the donation of hydrogen or lone pairs of electrons. Compounds such as hydroxyl group $(-\mathrm{OH})$ and amino groups $(-\mathrm{NH})$ in the chitosan are the important compounds that needed for antioxidant process. However, it is hard to be broken because of the semi-crystalline structure of chitosan with strong hydrogen bonds. Chitosan able to hinder the 1, 1diphenyl-2-picrylhydrazyl (DPPH) radical scavenging, superoxide anion radicals and hydrogen peroxide activities. $^{47}$

\section{Conclusion}

In recent years, various techniques of food preservation are available either for conventional or modern technology preservation methods. In this regard, the preservation methods used to preserve food should be suitable for the food conditions because not all of these methods are able to maintainthe freshness and organoleptic properties of the food products. As example, pickling will change their taste, texture and appearance. The choices of food preservation methods should depend on the purposes of the food use later on. Nevertheless, some conventional methods of food preservation have been upgraded by advanced technologies that present nowadays into methods that are compatible to be used by food industries such as drying.

The used of food preservatives have widely applied in food preservation to prevent the food borne pathogen. Natural preservatives have gained interest due to the awareness on the effect of consuming artificial preservatives. The used of preservatives can extend shelf life and maintain the organoleptic properties of the foods. Natural preservatives commonly are coming from plants, animals and microbes origin. There are many types of natural sources that are still not being studied to be used as food preservatives. The presence of active compounds such as phenolic acids, flavonoids, quinone, tannins and so forth in the natural sources will act as the antimicrobial and antioxidant agents.

\section{Acknowledgements}

Assists from the Faculty of Chemical Engineering, University Technology MARA (UiTM) Malaysia and financial support from LESTARI (UiTM) (600RMI/DANA 5/3/LESTARI (30/2015)) are gratefully acknowledged.

\section{References}

1. M. S. Rahman, "Food Preservation: Overview," Handbook of Food Preservation, 2nd Edition, London, CRC Press, pp. 3-7, 2007.

2. A. Ottoboni and F. Ottoboni, "The Food Guide Pyramid: Will the Defects Be Corrected?," Journal American of Physician Surgeon, vol. 9, no. 4, pp. 109-113, 2004.

3. K. Seetaramaiah, A. A. Smith, R. Murali, and R. Manavalan, "Preservatives in Food Products Review," Internatinal Journalof Pharmaceutical and Biological Archive, vol. 2, no. 2, pp. 583-599, 2011.

4. M. P. Devi, N. Bhowmick, M. R. Bhanusree, and S. K. Ghosh, "Preparation of Value-Added Products Through Preservation," Springer India, vol. 1, no. 1, pp. 113-124, 2015.

5. S. R. Rosa, "Postharvest Management of Fruit and Vegetables in the Asia-Pacific," 1st edition, Tokyo, Asian Productivity Organization, 2006.

6. D. M. Barrett and B. Lloyd, "Advanced preservation methods and nutrient retention in fruits and vegetables," Journal of the Science of Food and Agriculture, vol. 92, no. 1, pp. 7-22, 2012.

7. I. F. James and B. Kuipers, "Preservation of fruit and vegetables," 4th edition, no. 3. Wageningen, Agromisa Foundation, 2003.

8. B. Ingham, "Freezing Fruits and Vegetables," Madison, B3278, 2008.

9. C. Gambuteanu, D. Borda, and P. Alexe, "The Effect of Freezing and Thawing on Technological

CBangladesh Uni. of Engg.\&Tech 151 


\section{Chemical Engineering Research Bulletin 19(2017) 145-153}

Properties of Meat: Review," Journal of Agroalimentary Processes and Technologies, vol. 19, no. 1, pp. 88-93, 2013.

10. K. Kim, J. Shim, S. Yoo, S. Min, S. Lee, Y. Jo, and M. Choi, "Effects of various freezing and thawing techniques on pork quality in ready-to-eat meals," African Journal of Food Science, vol. 9, no. 1, pp. 525-533, 2015.

11. L. T. Nguyen, A. Tay, V. M. Balasubramaniam, J. D. Legan, E. J. Turek, and R. Gupta, "LWT - Food Science and Technology Evaluating the impact of thermal and pressure treatment in preserving textural quality of selected foods," LWT - Food Science Technology, vol. 43, no. 3, pp. 525-534, 2015.

12. P. S. Kadam, B. A. Jadhav, R. . Salve, and G. . Machewad, "Review on the High Pressure Technology (HPT) for Food Preservation," Journal of Food Processing and Technology, vol. 3, no. 1, pp. 1-5, 2012.

13. M. M. H. Senna, K. M. Al-Shamrani, and A. S. Al-Arifi, "Edible Coating for Shelf-Life Extension of Fresh Banana Fruit Based on Gamma Irradiated Plasticized Poly(vinyl alcohol)/Carboxymethyl Cellulose/Tannin Composites," Materials Sciences and Applications, vol. 5, no. 6, pp. 395-415, 2014.

14. M. R. Corbo, B. Speranza, D. Campaniello, D. D. Amato, and M. Sinigaglia, "Fresh-cut fruits preservation: current status and emerging technologies," Current research, technology and education topics in applied microbiology and microbial biotechnology, Formatex Reseach Center, Badajoz, pp. 1143-1154, 2010.

15. R. K. Dhall, "Advances in Edible Coatings for Fresh Fruits and Vegetables: A Review Advances in Edible Coatings for Fresh Fruits and Vegetables," Critical Reviews in Food Science and Nutrition, vol. 8398, no. 1, 2016.

16. P. K. Sabharwal, M. Garg, S. D. Sadhu, H. Khas, and N. Delhi-, "Advancement in conventional packaging - edible," World Journal of Pharmaceutical and Life Science, vol. 2, no. 3, pp. 160-170, 2016.

17. C. Pérez-Pérez, C. Regalado-González, C. A. Rodríguez-Rodríguez, and F. Barbosa-Rodríguez, J. R. Villaseñor-Ortega, "Incorporation of antimicrobial agents in food packaging films and coatings," Advances in Agricultural and Food Biotechnology, vol. 661, no. 2, pp. 193-216, 2006.

18. J. Inetianbor, J. Yakubu, and S. Ezeonu, "Effects of food additives and preservatives on man-a review," Asian Journal of Science and Technology, vol. 6, no. 2, pp. 1118-1135, 2016.

19. S. P. Anand and N. Sati, "Artificial preservatives and their harmful effects: looking toward nature for safer alternatives," International Journal of
Pharmaceutical Sciences and Research, vol. 4, no. 7, pp. 2496-2501, 2013.

20. H. A. Abdulmumeen, A. N. Risikat, and A. R. Sururah, "Food: Its preservatives, additives and applications," International Journal of Chemical and Biochemical Science, vol. 1, pp. 36-47, 2012.

21. P. M. Davidson, J. N.Sofos, and A. L.Branen, "Antimicrobials In Food,"3rd Edition, New York, Taylor \& Francis Group, 2005.

22. R. Gyawali and S. A. Ibrahim, "Natural products as antimicrobial agents," Food Control, vol. 46, no. 1, pp. 412-429, 2014.

23. I. D. Ciocan and I. I. Bara, "Plant products as antimicrobial agents," Genetic and Molecular Biology, vol. 8, no. 2, pp. 151-156, 2007.

24. I. H. N. Bassolé and H. R. Juliani, "Essential oils in combination and their antimicrobial properties," Molecules, vol. 17, no. 4, pp. 3989-4006, 2012.

25. V. Bobbarala, "Antimicrobial Agents," 2nd Edition, India, InTech, 2012.

26. S. A. Hayek, R. Gyawali, and S. A. Ibrahim, "Antimicrobial Natural Products," Microbial pathogens and strategies for combating them: science, technology and education, vol. 1 , no. 1 , pp. 910-921, 2013.

27. R. G. Bitencourt, A. M. M. Possas, G. P. Camilloto, R. S. Cruz, C. G. Otoni, and N. de F. F. Soares, "Antimicrobial and aromatic edible coating on fresh-cut pineapple preservation," Ciência Rural, vol. 44, no. 6, pp. 1119-1125, 2014.

28. T. Hintz, K. K.Matthews, and R. Di, "Review: The use of plant antimicrobial compounds for food preservation," Hindawi (BioMed Research International), pp. 1-12, 2015.

29. N. Matan, "Antimicrobial activity of edible film incorporated with essential oils to preserve dried fish (Decapterus maruadsi)," International Food Research Journal, vol. 19, no. 4, pp. 1733-1738, 2012.

30. A. Lucera, C. Costa, A. Conte, and M. A. Del Nobile, "Food applications of natural antimicrobial compounds," Frontiers in Microbiology, vol. 3, no. 8, pp. 1-13, 2012.

31. C. A. Murdock, J. Cleveland, K. R. Matthews, and M. L. Chikindas, "The synergistic effect of nisin and lactoferrin on the inhibition of Listeria monocytogenes and Escherichia coli," Journal Compilation The Society For Applied Microbiology, vol. 44, no. 1, pp. 255-261, 2007.

32. B. K. Tiwari, V. P. Valdramidis, C. P. O'Donnell, K. Muthukumarappan, P. Bourke, and P. J. Cullen, "Application of natural antimicrobials for food preservation," Journal of Agricultural and Food Chemistry, vol. 57, no. 14, pp. 5987-6000, 2009.

33. H. M. Abdelsamei, S. A. El Sohaimy, and M. A. Saad, "Effect of storage on the activity of the 


\section{Chemical Engineering Research Bulletin 19(2017) 145-153}

bacteriocin extracted from," Benha Veterinary Medical Journal, vol. 28, no. 1, pp. 216-222, 2015.

34. K. Jeevaratnam, M. Jamuna, and A. S. Bawa, "Biological preservation of foods - Bacteriocins of lactic acid bacteria," Indian Journal of Biotechnology, vol. 4, no. 10, pp. 446-454, 2005.

35. S. Punyauppa-path and P. Phumkhachorn, "Nisin: production and mechanism of antimicrobial action," International of Current Research, vol. 7, no. 2, pp. 47-53, 2015.

36. M. Soares, A. Fernandes, D. Carvalho, A. Clarissa, A. Aparecida, C. Souza, P. Henrique, D. Sobral, J. César, J. De Paula, and A. De Lima, "The effects of nisin on Staphylococcus aureus count and the physicochemical properties of Traditional Minas Serro cheese," International Dairy Journal., vol. 21, no. 2, pp. 90-96, 2011.

37. Skurtys O., Acevedo C., Pedreschi F., Enrione J., and Osorio F., "Food Hydrocolloid Edible Films and Coatings," Science \& Engineering, vol. 1, no. 1, pp. 34, 2001.

38. C. Kaur and H. C. Kapoor, "Inhibition of enzymatic browning in apples, potatoes and mushrooms," Journal of Scientific and Industrial Research, vol. 59, no. 5, pp. 389-394, 2000.

39. I. Ioannou and M. Ghoul, "Prevention of enzymatic browning in fruits and vegetables," European Scientific Journal., vol. 9, no. 30, pp. 310-341, 2013.

40. S. Dwivedi, M. N.Vasavada, and D. Cornforth, "Evaluation of Antioxidant Effects and Sensory Attributes of Chinese 5-Spice Ingredients in Cooked Ground Beef," Journal of Food Chemistry, vol. 71, no. 1, pp c-12-c17, 2006.

41. I. Marin, E. Sayas-Baebera, M. Viuda-Martos, C. Navarro, and E. Sendra, "Chemical Composition, Antioxidant and Antimicrobial Activity of Essential Oils from Organic Fennel, Parsley, and Lavender from Spain," Journal of Foods, vol. 18, no. 5, pp. 1-10, 2016.

42. K. Nugboon and K. Intarapichet, "Antioxidant and antibacterial activities of Thai culinary herb and spice extracts, and application in pork meatballs," International Food Research Journal, vol. 22, no. 5, pp. 1788-1800, 2015.

43. S. Supapvanich, P. Prathaan, and R. Tepsorn, "Postharvest Biology and Technology Browning inhibition in fresh-cut rose apple fruit cv. Taaptimjaan using konjac glucomannan coating incorporated with pineapple fruit extract," Postharvest Biology and Technology, vol. 73, no. 1, pp. 46-49, 2012.

44. N. Mahae, C. Chalat, and P. Muhamud, "Antioxidant and antimicrobial properties of chitosan-sugar complex," International Food Research Journal, vol. 18, no. 4, pp. 1543-1551,
2011.

45. L. S. Chua, N. L. A. Rahaman, N. A. Adnan, T. Tjih, and E. Tan, "Antioxidant Activity of Three Honey Samples in relation with Their Biochemical Components,"Journal of Analytic Methods in Chemistry, pp. 1-10, 2013.

46. N. Charernsriwilaiwat, P. Opanasopit, and T. Rojanarata, "In Vitro Antioxidant Activity of Chitosan Aqueous Solution : Effect of Salt Form," Tropical Journal of Pharmaceutical Research, vol. 11, no. 2, pp. 235-242, 2012.

47. A. Rajalakshmi, N. Krithiga, and A. Jayachitra, "Antioxidant Activity of the Chitosan Extracted from Shrimp Exoskeleton," Middle-East Journal of Scientific Research, vol. 16, no. 10, pp. 14461451, 2013.

48. A. Penyalutan and B. Averrhoa, "Application of palm stearin- chitosan edible coating on star fruits (Averrhoa carambola L.)," Malaysian Journal Analytical Science, vol. 16, no. 3, pp. 325-334, 2012.

49. R.P. Campos and M. de A. Rodovalho, "Coating on 'Camarosa' organic strawberries stored at low temperature,” Brazillian Journal, vol. 12, no. 1, pp. 60-67, 2009.

50. J. Malmiri and A. Rahman, "Development of an edible coating based on chitosan-glycerol to delay 'Berangan' banana ( Musa sapientum cv . Berangan ) ripening process," International Food Research Journal., vol. 18, no. 3, pp. 989-997, 2011.

51. R. A. Ghavidel, M. G. Davoodi, and A. F. Adib, "Effect of Selected Edible Coatings To Extend Shelf-Life Of Fresh-Cut Apples," International Journal of Agriculture and Crop Science, vol. 6, no. 16, pp. 1171-1178, 2013.

52. X. Zeng, Y. Duan, W. Zhe, J. Jiang, L. He, S. Wang, and M. Wang, "Edible coating based on soy protein to improve shelf life and overall quality of minimally processed jujubes," Journal of Food, Agriculture \& Environment, vol. 11, no. October, pp. 263-269, 2013.

53. M. Rakshit and C. Ramalingam, "Gum acacia coating with garlic and cinnamon as an alternate , natural preservative for meat and fish," African Journal Biotechnology, vol. 12, no. 4, pp. 406-413, 2013.

\section{Available online at}

http://www.banglajol.info/index $. p h p / C E R B$ 